\title{
Reading, Writing and Relevancy: Integrating 3R's into STEM
}

\author{
Shirley Lefever-Davis ${ }^{1, *}$ and Cathy J. Pearman ${ }^{2}$ \\ ${ }^{I}$ Wichita State University, Wichita, KS 67260, United States, ${ }^{2}$ Missouri State University, Springfield, MO 65897, United \\ States
}

\begin{abstract}
A recent editorial in the New York Times (Editorial, 2013) raised an awareness of a growing demand for more college graduates in the Science, Technology, Engineering and Math (STEM) fields. This fact, coupled with a declining interest on the part of students in those areas (ACT, 2013) necessitates a dramatic and urgent need for K-12 curriculum that fosters an interest in these fields and promotes skills that facilitate success. Many educators believe the solution is a curriculum steeped in a problem-based approach that integrates strong communication skills (Sanders, 2009). This article will describe the importance and essence of making STEM instruction relevant through a problem-based learning approach at the same time promoting students' literacy skills. Specific suggestions for instructional strategies that can be used effectively in a problem-based curriculum to promote competence and interest in STEM areas will also be described.
\end{abstract}

Keywords: Problem-based learning, reading, STEM, writing.

\section{INTRODUCTION}

Today's global economy requires a workforce that is adept in Science, Technology, Engineering and Math (STEM). An emphasis on quality STEM education is considered essential to provide students with the requisite skills to navigate the modern world and grant them access to growing career opportunities for success. Approaches to developing today's students with these skills begin with a problem-based curriculum that integrates literacy strategies to develop conceptual understandings of science and math content and processes.

\section{LITERATURE REVIEW}

\section{STEM Education and Tomorrow's Work Force}

It is widely recognized there is a critical need for excellence in science, technology, engineering, and mathematics talent for future technology and innovation for the U.S. to compete globally, ensure national security and respond to the growing demand for STEM workforce. According to an editorial in the New York Times (Editorial, 2013), in the next five years, the fastest growing occupations are those where science and math expertise are key with over 2.4 million STEM related job openings anticipated. At the same time demand for a highly skilled workforce is growing, there is evidence that student interest in STEM fields is declining. A recent publication by (ACT, 2013) indicated nearly $90 \%$ of America's high school students are not interested in pursuing a college major or career in those fields.

While many factors are likely contributing to this lack of interest in STEM areas, there is growing interest among educators and policy makers to address the issue by moving

*Address correspondence to this author at the Wichita State University, Wichita, KS 67260, United States; Tel: 316-978-3385; Fax: 316-978-6935; E-mail: shirley.lefever-davis@wichita.edu to problem-based learning or more integrative approaches to STEM education. These approaches are well supported by research on constructivist theory which concludes: 1) learning is a constructive process, 2) motivation is central to understanding, 3) social interaction is essential to learning and 4) acquisition of new knowledge and skills is contextual (Sanders, 2009).

\section{Cognitive and Non-cognitive Benefits of Problem-based Learning}

The interest, motivation and achievement benefits of a problem-based learning approach to STEM education are receiving a great deal of attention from educators across the country. Those in the field of education fully appreciate the importance of interest and motivation on learning and recognize the power and potential of purposefully designed curriculum to enhance student involvement in inquiry (Sanders, 2009).

Problem-based learning interweaves cognitive and affective benefits. Through the use of problem-based learning strategies, STEM education connects students with real-world problems and sparks their curiosity, creativity, and innovation to explore and solve these problems (Roberts, 2013). A curriculum that offers a combination of theory and practice applied across disciplines fosters the development of problem-solving abilities and the integration of knowledge. Problem-based learning strategies help establish positive attitudes towards learning STEM concepts as students realize they must have multiple kinds of knowledge and abilities in order to solve problems. For example, applying concepts inherent in STEM subjects cultivates systematic thinking, technical cognition, mechanical application, and mathematical calculation abilities. Learner satisfaction increases as students realize they must take the initiative to gather resources, decide directions of explorations, and apply knowledge to solve an existing problem. These opportunities often lead to student modifications of a task or problem 
further motivating students and heightening their interest in learning (Lou et al., 2011).

\section{Digital Literacy and Collaborative Learning in STEM}

(The Massachusetts Department of Education, 2014) identified STEM standards that help frame the STEM curriculum and emphasize digital literacy as a key component. Creative thinking and the ability to approach learning from many perspectives enhances the ability of the learner to engage in authentic, problem-based learning. The goal of STEM education is to integrate science, technology, engineering, and math into one class, or even one lesson, which is linked to the solving or contemplation of real-world problems. To achieve this end, students may encounter information in many formats, such as data tables, computer simulations, virtual experiences, and practice scenarios (Moore \& Smith, 2014). Competence in digital literacies is crucial for the correct interpretation and utilization of these information formats.

The value of cooperative and collaborative learning in interdisciplinary, project-based learning is well documented (Chen \& Chang, 2014; Fifolt \& Searby, 2010; Tartas \& Mirza, 2007; Shooter \& McNeill, 2002). The Center for Teaching and Faculty Excellence at George Mason (2014) promoted collaborative learning approaches stating collaborative learning strengthens STEM education by valuing the diversity of student learning styles and emphasizing that learning occurs in relationship with others. Digital literacies fulfill this function as students are able to not only share projects across geographical space, but to also jointly prepare charts, graphs, and tables to better express their ideas and findings. This sharing of information and ideas allows conclusions to be based on multiple perspectives. Perhaps more importantly, students can collaborate to actually develop the technologies necessary to display projects and construct knowledge. This ability to use digital literacies to solve problems and create solutions is in adherence with the core purpose of STEM.

While there is general agreement that everyone needs to be STEM literate, there is wide variation in what that means. A growing number of researchers are recognizing the need for creative and communication skills to ensure America's competitiveness including (Tarnoff, 2010) who argued tomorrow's workforce needs innovators who possess the creativity and communication skills to develop products and services that will drive the global economy. This argument for STEM Literacy was further defined by (Zolman, 2012) to include the need to fulfill personal needs as well as societal and economic needs. More specifically, he stated STEM literacy needs to extend beyond content and process and must also include the ability to communicate complex ideas to a wide variety of audiences. In addition, he argued that cognitive and affective learning domains must be developed in order for learners to possess not only STEM knowledge but also the attitudes, motivation, interest and selfconfidence to produce students who value STEM areas.

Cognitive domains are addressed when students are engaged in acquiring conceptual understanding and application of content. Reflecting on learning further solidifies conceptual understanding and application of content. Affective domains include attention to fostering student interest, motivation and self-determination, and are often promoted via an engaging classroom environment. These constructs have formed the basis for STEM instruction and the call for problem-based learning as an effective method for achieving curricular goals (Bruce-Davis et al., 2014).

\section{Promoting STEAM Learning through Literacy}

Responding to the need to ensure every child is equipped for college and careers, many of which will be in STEM fields, many states have worked together to articulate a set of Common Core State Standards (CCSS) to ensure a researched based, rigorous curriculum for today's students. At the heart of promoting learning in STEM areas is the need for strong literacy skills. In developing standards for the Common Core English Language Arts, states have articulated a definition of what it means to be literate to include strong content knowledge and the ability to be discerning readers and listeners (Common Core State Standards Initiative, 2014). For example, in today's world, to be literate requires students to be able to use and understand vocabulary specific to each domain, the ability to critically interpret and analyze multiple types of texts as well as the ability to express those understandings in creative ways. Partly due to the complexity of this endeavor, the wide array of curriculum products rapidly appearing on the market is presenting many challenges for educators as these products sometimes convey conflicting messages about implementing those standards. To aid in communicating effective approaches at implementing the CCSS, (International Reading Association, 2012) has issued a set of guidelines for the implementation of the English Language Arts Common Core State Standards. Among these guidelines are the recommendations to use challenging texts, teach foundational skills (such as phonological awareness and fluency), focus on comprehension, develop writing skills and to acquire disciplinary literacy (International Reading Association, 2012). Disciplinary literacy is defined as a focus on the distinct manner in which reading, writing and language are used in specific content disciplines and practices that engage students in ways of thinking and communication particular to each field (International Reading Association, 2012).

Dorothy Strickland (2012) offers a framework for curriculum planning for implementing the CCSS that outlines key considerations consistent with problem-based approaches to instruction. The planning framework begins with identifying a topic of inquiry-based on local standards and gathering texts, displays and other resources to stimulate interest and discussion. To develop lines of inquiry, teachers are encouraged to collaborate with students to articulate essential questions or problems to drive student engagement with the content. To initiate the line of inquiry, (Morrow, 2012) emphasizes the importance of providing an abundance of texts both narrative and informative on the topic for students to read independently and with teacher support. Access to a wide range of texts is instrumental to promoting student interest and engagement in the topic.

Problem-based learning approaches utilize a range of literacy strategies to develop student understanding of these concepts and to intentionally promote language skills. 
(The Massachusetts Department of Elementary and Secondary Education, 2014) has made available Model Curriculum Units that integrate literacy strategies with the intent to support content learning. Rubrics included with the model units assess the degree to which unit employ problembased learning approaches intended to engage students in relevant, authentic learning. The rubrics developed to assess the quality of each model unit also include criteria for evaluating the use of literacy to support student content learning. Those criteria include exercises that support student disciplinary learning and engage them in the use of informational text and writing. Literacy strategies used effectively to promote learning in a problem-based learning environment address the full spectrum of literacy goals (and standards) including vocabulary development, comprehension, fluency, and writing development.

The International Reading Association has published a Strategy Guide (Simon, 2014) describing the Think-PairShare Technique as one example of a literacy strategy used to support student learning by promoting active participation. This comprehension strategy engages students in a process of reflecting on their understanding of a text and then sharing their understandings with a peer. After the two have discussed their individual interpretations of the text, they work together to arrive at a shared understanding of the text and generate a conclusion they report out to the larger group.

Graphic organizers are another strategy used to guide students in their exploration of a topic. Venn diagrams are graphic organizers that are used to compare and contrast key vocabulary, concepts and processes. Graphic organizers are an effective strategy for learners because they help learners see how concepts are related and offer a straightforward approach to organizing their understanding. This visual representation of content can then be used to help students' articulate their understandings through a written response such as informative or explanatory texts.

Student understanding of STEM content can also be fostered through more creative expressions such as poetry or narrative prose. A plethora of formula poems and non-verbal representations of content have been used effectively by teachers to engage students in critical thinking and interpretation of content. Engaging students in these types of creative expression promotes visualization and imagery of the concept thus deepening understanding and opening up possible connections to other disciplines. One such example of this is described by (Curtis et al., 2014) in their curriculum unit on Traditions. In this unit, students prepare and participate in a Readers Theatre performance as part of a culminating project designed as an opportunity to communicate their understandings of the unit's curriculum goals.

Another comprehension building strategy used effectively in STEM related investigations is instruction on text structures. Developing student awareness and recognition of text structures can reduce cognitive demands placed on students when reading, allowing them to focus more heavily on content. To explain further, when students are taught to recognize text features such as signal words, the specific text structure is illuminated and students are able to anticipate content that may be included in the text. A graphic organizer such as a flow chart that includes those signal words is an effective strategy for helping students discover text structure. Such a flow chart can be used as a visual outline for students to fill in content from the text and anticipate upcoming information.

\section{BENEFITS OF PROBLEM-BASED LEARNING IN STEM}

In response to the critical need for increasing numbers of individuals in STEM related occupations, (The White House Office of the Press Secretary published a Fact Sheet: Youth CareerConnect Grants, 2013) that announced a new initiative to promote STEM education. There is growing consensus that school curricula must not only promote student knowledge and skill in STEM related content and processes, but it must also promote student interest in those fields. Problem-based learning offers an approach to curriculum that addresses the cognitive and non-cognitive aspects of student learning. It enhances student motivation and interest in STEM areas at the same time it fosters literacy learning and deep understanding of STEM content and processes. A wide range of literacy strategies have been used effectively to promote student literacy skills within a problem-based curriculum based on inquiry consistent with STEM disciplines. Drawing on constructivist theory and research, problem-based learning promotes student understanding by engaging them in inquiry on topics of personal interest. Developing deep connections to STEM areas through a problem-based curriculum promotes student interest and self-determination in accomplishing complex tasks. This sustained involvement with STEM content ultimately has a positive impact on student learning and can help address the critical need for more students to pursue this area.

\section{CONFLICT OF INTEREST}

The authors confirm that this article content has no conflict of interest.

\section{ACKNOWLEDGEMENTS}

Declared none.

\section{REFERENCES}

ACT. (2013). The condition of college and career readiness. Retrieved from http://www.act.org/research/policymakers/cccr13/pdf/CCCR13NationalReadinessRpt.pdf

Bruce-Davis, M.N., Gubbins, E.J., Gilson, C.M., Villanueva, M., Foreman, J.L., \& Rubenstein, L.D. (2014). STEM high school administrators', teachers', and students' perceptions of curricular and instructional strategies and practices. Journal of Advanced Mathematics, 25(3), 272-306.

Center for Teaching and Faculty Excellence. (2014). Collaborative learning. George Mason University. Retrieved from http://ctfe.gmu.edu/teaching/collaborative-learning/

Chen, C-M., \& Chang, C-C. (2014). Mining learning social networks for cooperative learning with appropriate learning partners in a problem-based learning environment. Interactive Learning Environments, 22(1), 97-124.

Common Core State Standards Initiative. (2014). English language arts standards: Introduction: Students who are college and career ready in reading, writing, speaking, listening and language. Retrieved from http://www.corestandards.org/ELA-Literacy/introduction/ students-who-are-college-and-career-ready-in-reading-writingspeaking-listening-language/

Curtis, L., Lohfink, G., \& Hohl, E. (2014). Traditions: Multicultural literature and the inquiry approach for primary grades. IRA 
Bridges: Instructional Units for the Engaging Classroom. Retrieved September 12, 2014 from http://www.reading.org/general/Publications/bridges/7005

Editorial: Who says math has to be boring? [Editorial]. (2013). The New York Times. Retrieved from http://www.nytimes.com/ 2013/12/08/opinion/sunday/who-says-math-has-to-beboring.html? $\mathrm{r}=1 \&$

Fifolt, M., \& Searby, L. (2010). Mentoring in cooperative education and internships: Preparing protégés for STEM professions. Journal of STEM Education, 11(1), 17-26.

International Reading Association Common Core State Standards (CCSS) Committee. (2012). Literacy implementation guidance for the ELA Common Core State Standards [White paper]. Retrieved from http:/www.reading.org/general/AboutIRA/white-papers/elacommon-core-standards.aspx

Lou, S-J., Shih, R-C., Diez, C.R., \& Tseng, K-H. (2011). The impact of problem-based learning strategies on STEM knowledge integration and attitudes: An exploratory study among female Taiwanese senior high school students. International Journal of Technology and Design Education, 21, 195-215.

Massachusetts Department of Elementary and Secondary Education. (2014). Science, technology, engineering, and mathematics (STEM). Retrieved from http://www.doe.mass.edu/STEM/ca.html

Moore, T.J., \& Smith, K.A. (2014). Advancing the state of the art of STEM integration. Journal of STEM Education, 15(1), 5-10.
Morrow, L.M. (2012). A primary grade science unit using the Language Arts/Literacy Common Core State Standards. Reading Today, 29(5), 29-30.

Roberts, A. (2013). STEM is here. Now what? Technology and Engineering Teacher, 37(1), 22-7.

Sanders, M. (2009). STEM, STEM education, STEMmania. The Technology Teacher, 68(4), 20-6.

Shooter, S., \& McNeill, M. (2002). Interdisciplinary collaborative learning in mechatronics at Bucknell University. Journal of Engineering Education, 91(3), 339-44.

Simon, C.A. (2014). Strategy guide: Using the Think-pair-share technique. Retrieved from http://www.readwritethink.org/professionaldevelopment/strategy-guides/using-think-pair-share-30626.html

Strickland, D. (2012). Planning curriculum to meet common core state standards. Reading Today, 29(4), 25-6.

Tarnoff, J. (2010). STEM to STEAM - Recognizing the value of creative skills in the competitive debate. Retrieved from http://steamnotstem.com/articles/stem-to-steam

Tartas, V., \& Mirza, N.M. (2007). Rethinking collaborative learning through participation in an interdisciplinary research project: Tensions and negotiations as key points in knowledge productions. Integrative Psychological and Behavioral Science, 41(2), 182-8.

The White House, Office of the Press Secretary. (2013). Fact sheet: Youth careerConnect grants. Retrieved from http://www.whitehouse.gov/ the-press-office/2013/11/19/fact-sheet-youth-careerconnect-grants

Zollman, A. (2012). Learning for STEM literacy: STEM literacy for learning. School Science and Mathematics, 112(1), 12-19.

Received: September 15, 2014

Revised: December 08, 2014

Accepted: February 02, 2015

(C) Lefever-Davis and Pearman; Licensee Bentham Open.

This is an open access article licensed under the terms of the Creative Commons Attribution Non-Commercial License (http://creativecommons.org/licenses/by-nc/3.0/) which permits unrestricted, non-commercial use, distribution and reproduction in any medium, provided the work is properly cited. 